University of Nebraska - Lincoln

DigitalCommons@University of Nebraska - Lincoln

1998

\title{
Herbivore Adaptations to a Low-Nutrient Food: Weed Biological Control Specialist Spodoptera pectinicornis (Lepidoptera: Noctuidae) Fed the Floating Aquatic Plant Pistia stratiotes
}

G. S. Wheeler

Aquatic Weed Research Unit, USDA-ARS, 3205 College Avenue, Ft. Lauderdale, FL 33314

T. K. Van

Aquatic Weed Research Unit, USDA-ARS, 3205 College Avenue, Ft. Lauderdale, FL 33314

T. D. Center

Aquatic Weed Research Unit, USDA-ARS, 3205 College Avenue, Ft. Lauderdale, FL 33314

Follow this and additional works at: https://digitalcommons.unl.edu/entomologyother

Part of the Entomology Commons

Wheeler, G. S.; Van, T. K.; and Center, T. D., "Herbivore Adaptations to a Low-Nutrient Food: Weed Biological Control Specialist Spodoptera pectinicornis (Lepidoptera: Noctuidae) Fed the Floating Aquatic Plant Pistia stratiotes" (1998). Entomology Papers from Other Sources. 88.

https://digitalcommons.unl.edu/entomologyother/88

This Article is brought to you for free and open access by the Entomology Collections, Miscellaneous at DigitalCommons@University of Nebraska - Lincoln. It has been accepted for inclusion in Entomology Papers from Other Sources by an authorized administrator of DigitalCommons@University of Nebraska - Lincoln. 
Biological Control

\title{
Herbivore Adaptations to a Low-Nutrient Food: Weed Biological Control Specialist Spodoptera pectinicornis (Lepidoptera: Noctuidae) Fed the Floating Aquatic Plant Pistia stratiotes
}

\author{
G. S. WHEELER, T. K. VAN, AND T. D. CENTER
}

Aquatic Weed Research Unit, USDA-ARS, 3205 College Avenue, Ft. Lauderdale, FL 33314

\begin{abstract}
Environ. Entomol. 27(3): 993-1000 (1998)
ABSTRACT Performance of the specialist herbivore Spodoptera pectinicornis (Hampson) was studied when fed the floating aquatic plant waterlettuce, Pistia stratiotes $\mathrm{L}$. (Araceae). Plants were either collected from 6 populations in southern Florida or from plants grown with low or high fertilizer levels. Consumption of leaves with increasing toughness resulted in increased larval mortality (>80\%); most mortality occurred during the first 2 instars. Larvae compensated for low-nitrogen leaves by increasing fresh weight consumption 3-fold. Both developmental time and biomass gain were effected by the source of the plants but these performance parameters were not directly related to either leaf toughness or nitrogen levels. These results are useful in understanding the adaptations and limitations of specialist herbivores to low-nutrient foods. Additionally, they assist in the selection of suitable release sites for this weed biological control agent. Finally, they improve our mass-rearing techniques for augmentative releases of this biological control species.
\end{abstract}

KEY WORDS Pistia stratiotes, Spodoptera pectinicornis, weed biological control, nitrogen, leaf toughness, compensatory feeding

AQUATIC WEEDS CONSTITUTE significant threats to navigable waterways, flood control activities, and natural area biotic diversity, and are potential health threats (Holm et al. 1977, Lounibos and Escher 1985, Orr and Resh 1992). One of the most widely spread and important floating aquatic weeds in tropical and subtropical regions of the world, including the southeastern United States, is waterlettuce, Pistia stratiotes L. (Araceae) (Cook et al. 1974, Holm et al. 1977). Waterlettuce is a floating perennial that consists of a rosette of leaf blades that arise from a central meristem; a very short stem axis; and long feathery roots. Leaves are prominently veined below, covered with velvety hairs, and produced sequentially from the center of the rosette. The plant reproduces both vegetatively by stoloniferous daughter plants and by seeds (Dray and Center 1989).

Research to develop biological control of P. stratiotes has been conducted in Florida for over a decade (Center 1994). These activities have resulted in the release and establishment of a leaf-feeding weevil, Neohydronomous affinis Hustache, from South America (Dray et al. 1990). The weevil is widely distributed throughout the state and at some locations has had a significant impact on $P$. stratiotes populations, at best reducing the weed coverage to $5 \%$ of its previous level (Dray and Center 1992, Center 1994). However, the weed continues to be a problem as this level of control does not occur at all sites nor at all times. Therefore, additional biological control agents could supplement the control exerted by the weevil. The noctuid Spodoptera pectinicornis (Hampson) is a very effective control agent of $P$. stratiotes in Thailand (Napompeth 1982) and has been cleared for release in the United States (Habeck and Thompson 1994). Despite releases at numerous sites, field populations of this species may be only sporadically established and its general status at the remaining sites is unknown (Center 1994).

Knowledge of the factors that limit the performance (i.e., growth, development, and fecundity) of S. pectinicornis may improve our success in the establishment of this species by providing the information needed to select the most conducive release site (s) for rapid population growth. An important factor that frequently limits growth and development of herbivorous insects is the nutritional quality of plants, especially percentage of nitrogen (Mattson 1980) and leaf toughness (Coley and Barone 1996). The importance of plant nutritional factors for weed biological control has been shown for a number of other aquatic weeds, including alligatorweed, Alternanthera philoxeroides (Mart.) Griseb. (Amaranthaceae) (Maddox and Rhyne 1975); salvinia, Salvinia molesta Mitchell (Salviniaceae) (Taylor 1984, 1988; Room 1990); waterhyacinth, Eichhornia crassipes (Mart.) (Center 1994); and hydrilla, Hydrilla verticillata (L. f.) Royle (Hydrocharitaceae) (Wheeler and Center 1996, 1997). As with hydrilla, $P$. stratiotes may range widely at different sites in both the levels of nitrogen and leaf toughness. Therefore, some plant populations may be better suited than others for herbivore establishment and population increases. The goal of this study was to determine the range of nitrogen and leaf toughness at various sites in Florida and to determine their impact 
on the survival, growth, and development of the $P$. stratiotes biological control agent $S$. pectinicornis. Additionally, we compare these results with those from outdoor tank studies where larvae were fed leaves from plants grown at known fertilizer levels.

\section{Materials and Methods}

Plant Collections. P. stratiotes was collected from 6 potential release sites in southern Florida from November 1995 to January 1996. The sites, which consisted of small lakes or impoundments, included Torrey Island, Palm Beach County; Corkscrew Swamp Sanctuary, Collier County; Pioneer Park, Palm Beach County; Loxahatchee site 1, Palm Beach County; Loxahatchee site 2, Palm Beach County; and Christmas Park, Orange County. Collected plants were returned to our laboratory where the youngest 4 expanded leaves (counting from the central-most expanded leaf outward) were excised and refrigerated in moist plastic shoe boxes at $10^{\circ} \mathrm{C}$ until ready for feeding tests $(\approx 2 \mathrm{~d})$.

The effect of fertilizer on insect performance was determined using $P$. stratiotes plants (4-5 leaves per plant) grown outdoors in 64 -liter pots $\left(0.16-\mathrm{m}^{2}\right.$ surface area) inside $3 \mathrm{~m}$ long by $2 \mathrm{~m}$ wide by $0.75 \mathrm{~m}$ deep tanks at relatively high (high; 5 ppm nitrogen with Peter's [W. R. Grace, Fogelsville, PA] 15-5-15 and 2 ppm Fe, changed weekly) and low fertilizer rates (low; 0.25 ppm nitrogen with Peter's 15-5-15 and 0.1 ppm Fe, changed weekly). Each tank was screened with organdy cloth to prevent infestations by herbivores. This procedure reduced sunlight penetration by $45 \pm 1.0 \%$ (mean $\pm \mathrm{SE}$ ). Three or 4 plants were grown in each pot for the high and low fertilizer treatments, respectively, and each treatment was replicated 4 times. By growing the plants at different initial densities we avoided the morphological changes observed with different crowding and fertilizer conditions (Tucker 1981). The plants were grown for 4 mo (AugustDecember) until they completely covered the water surface of the pots in which they were grown. Leaves were cut from plants as needed and refrigerated as described above.

Plant Quality. Percentage of nitrogen, phosphorus, and potassium (all dry weight) were determined on leaves 1-4 collectively (without regard to position) of all field-collected and cultured plants. Leaf digests were conducted by a Kjeldahl method (Hach et al. 1987). Nitrogen content of leaves was determined by the ammonia-selective electrode method, phosphorus by the ascorbic acid method, and potassium by atomic absorption chromatography (Greenberg et al. 1992). Standard reference materials (tomato leaves; National Institute of Standards and Technology, Gaithersburg, MD) were analyzed as controls and values were adjusted for percentage of recovery. Tests were replicated 4 times, and each replicate consisted of the bulked leaves from the 4 leaf positions of 25 plants.

Leaf toughness was measured using a gram gauge (Halda, Stockholm, Sweden) modified with a 0.52 mm-diameter blunt probe that measured the force required to puncture leaf tissues (Wheeler and Center 1996, 1997). Measurements were recorded for each leaf position (1-4) and from 4 locations on each leaf: the tip, apical quarter, halfway point where the leaf begins to enlarge, and the base. Toughness measurements of each leaf position and location within the leaf were replicated 40 times per site. Leaf percentage of dry weight $(n=20)$ was determined gravimetrically by weighing each leaf fresh and after drying for $48 \mathrm{~h}$ at $60^{\circ} \mathrm{C}$.

Larval Survival, Growth, and Development. Neonate $S$. pectinicornis larvae $(n=40)$ were collected from a laboratory colony that had been in culture for 6 mo ( $\approx 6$ generations) without infusion of wild genotypes. This colony had been cultured continuously in outdoor tanks on live plants. Each neonate was transferred to a leaf and reared through to pupation. The leaves fed to the larvae were selected randomly from among leaf positions $1-4$. The larvae were reared individually in plastic petri dishes $(15$ by $3 \mathrm{~cm}$ ) lined with moistened filter paper and sealed with Parafilm. All rearing was conducted at $28^{\circ} \mathrm{C}, 50 \% \mathrm{RH}$, and a photoperiod of 14:10 (L:D) h. The final location of the larvae was recorded, namely whether the larvae were located internally or externally, on the leaf apical or basal half, and on the upper or lower leaf surface. Data also were collected on larval survival, consumption, growth and developmental time to the pupal stage. Leaf consumption was estimated gravimetrically on an electronic balance (Mettler AC-100, $\pm 0.1 \mathrm{mg}$ ) according to the following method. Each leaf was cut lengthwise and each half was weighed fresh. One half served as the control leaf and was dried $\left(60^{\circ} \mathrm{C}\right.$ for $\left.48 \mathrm{~h}\right)$ directly to estimate the initial percentage of dry weight of the entire leaf and the other half was fed to a larva. Leaves were replaced when $>60 \%$ of the leaf half had been consumed. Generally, each larva was refed only once. The uneaten portion of this leaf half was dried and weighed. With the estimate of initial dry weight and the final dry weight of the leaf material remaining, we could estimate dry weight consumption by subtracting the final dry weight from the estimated initial dry weight. Fresh weight consumption was estimated by dividing the amount consumed (dry weight) by the proportion of leaf dry weight. Initial larval dry weight was estimated with a cohort $(n=10)$ of neonate larvae weighed fresh and after drying. Larval growth was estimated by subtracting the estimated initial dry weight from the final dry weight of the pupae.

Data Analysis. All analyses were conducted with SAS/PC (PROC GLM) unless otherwise noted (SAS Institute 1988). Analysis of variance (ANOVA) was conducted to determine if leaf nitrogen, potassium, phosphorus, and dry weight varied among treatments. To determine if leaf toughness varied among treatments, leaf positions or leaf locations within a leaf, a nested ANOVA was conducted, where leaf location on a leaf was nested within leaf position on a plant and leaf position was nested within plants collected at each site. A $G$ test was used to determine if larval location varied within leaves, using the William's correction for 
Table 1. Composition (mean \pm SE) of leaves of $P$. stratiotes plants that were either field collected or cultured with low or high levels of fertilizer

\begin{tabular}{|c|c|c|c|c|c|}
\hline \multirow[t]{2}{*}{ Treatment $^{a}$} & $\mathbf{N}^{b}$ & $\mathrm{PO}_{4}^{b}$ & $\mathbf{K}^{b}$ & $\begin{array}{c}\text { Dry } \\
\text { weight }^{c}\end{array}$ & Toughness $^{d}$ \\
\hline & $\% \pm \mathrm{SE}$ & $\% \pm \mathrm{SE}$ & $\% \pm \mathrm{SE}$ & $\% \pm \mathrm{SE}$ & $\mathrm{g} / \mathrm{mm}^{2} \pm \mathrm{SE}$ \\
\hline $\mathrm{CM}$ & $2.8 \pm 0.1 \mathrm{a}$ & $0.44 \pm 0.04 \mathrm{bc}$ & $5.1 \pm 0.1 \mathrm{abc}$ & $8.9 \pm 0.3 \mathrm{a}$ & $349.6 \pm 5.6 \mathrm{a}$ \\
\hline HIGH & $2.6 \pm 0.1 \mathrm{a}$ & $0.70 \pm 0.01 \mathrm{a}$ & $5.4 \pm 0.2 \mathrm{a}$ & $4.9 \pm 0.2 \mathrm{f}$ & $140.6 \pm 1.5 \mathrm{e}$ \\
\hline LOX-2 & $2.5 \pm 0.2 \mathrm{a}$ & $0.54 \pm 0.03 b$ & $3.9 \pm 0.3 \mathrm{bc}$ & $8.6 \pm 0.2 \mathrm{a}$ & $269.6 \pm 5.1 \mathrm{~b}$ \\
\hline $\mathrm{CS}$ & $1.5 \pm 0.1 b$ & $0.26 \pm 0.02 \mathrm{~d}$ & $4.8 \pm 0.5 \mathrm{abc}$ & $6.3 \pm 0.1 \mathrm{de}$ & $190.3 \pm 3.1 d$ \\
\hline TOR & $1.5 \pm 0.2 b$ & $0.45 \pm 0.04 b c$ & $4.6 \pm 0.4 \mathrm{abc}$ & $7.8 \pm 0.2 b$ & $247.2 \pm 3.9 c$ \\
\hline
\end{tabular}

Means within a column followed by the same letter are not significantly different (Ryan $Q, P=0.05$ ).

${ }^{a}$ LOX-1, Loxahatchee site 1; CM, Christmas Park; HIGH, high fertilizer; LOX-2, Loxahatchee site 2; LOW, low fertilizer; PP, Pioneer Park; CS, Cork Screw; TOR, Torrey Island.

${ }^{b} n=4$.

${ }^{c} n=20$.

${ }^{d} n=40$.

${ }^{e} \mathrm{ND}$, not determined.

the 2-cell case (Sokal and Rohlf 1981). To determine if the treatments influenced the instar in which death or pupation occurred the data were analyzed with ANOVA. Stepwise multiple regression (PROC REG) was conducted to determine which plant nutritional factors (i.e., leaf nitrogen, phosphorus, potassium, dry weight, and toughness) significantly influenced larval performance (i.e., survival, consumption, weight gain, and developmental time). Additionally, the influence of the interaction of percentage nitrogen and toughness was determined on larval performance. The stepwise regression was conducted such that only those plant nutritional factors with a $5 \%$ significance level remained in the model (Draper and Smith 1981). For those performance parameters that were not significantly related to plant nutritional factors (i.e., developmental time and biomass gain; see Results), ANOVA was conducted to determine if differences occurred among the treatments in the performance parameters. Correlations (PROC CORR) were conducted among the plant nutritional factors to determine their degree of relatedness. Means for leaf quality and larval performance were compared with the Ryan $Q$ test ( $P=$ 0.05; Day and Quinn 1989).

\section{Results}

Plant Quality. The P. stratiotes leaves from different sources varied significantly in nitrogen $(F=26.2 ; \mathrm{df}=$ $7,24 ; P<0.0001)$, potassium $(F=3.9 ; d f=7,24 ; P=$ $0.0059)$, phosphorus $(F=22.2 ; d f=7,24 ; P<0.0001)$, and percentage of dry weight $(F=57.8 ; d f=7,485$; $P<0.0001$; Table 1). The Loxahatchee-1, Christmas Park, high, and Loxahatchee-2 leaves had the highest nitrogen concentrations. Phosphorous concentrations were highest in leaves from the high treatment and lowest in the Pioneer Park and Corkscrew collections. Potassium content was lowest in the Loxahatchee-2 and low treatments. Percent dry weight of leaves was highest in the Christmas Park and Loxahatchee-2 treatments and lowest in the low and high fertilizer treatments.
Leaf toughness differed significantly among the treatments $(F=169.80 ; \mathrm{df}=6,1080 ; P<0.0001)$. The toughest leaves were collected at the Christmas Park site, where values ranged from 310 to $405 \mathrm{~g} / \mathrm{mm}^{2}$ (Table 1). The high fertilized leaves had the lowest toughness values, followed by the low fertilizer and Corkscrew leaves. Leaf toughness was not determined for plants from the Pioneer Park site. Leaf toughness also varied at different locations on leaves $(F=21.68$; $\mathrm{df}=12,1,080 ; P<0.0001)$. The highest toughness measurements were found halfway between the leaf tip and base, which was the location where the leaf first becomes thickened (Fig. 1). Leaf toughness did not differ significantly among leaf positions $1-4$ ( $F=$ $0.10 ; \mathrm{df}=18,1080 ; P=1.0$ ). Moreover, correlations among the plant nutritional factors suggested that only leaf toughness and percentage of dry weight were significantly related (Table 2 ).

Larval Location. The surviving larvae were most frequently encountered on the upper $(80.5 \%$; $G=$ $16.56, \mathrm{df}=1, P=0.005$ ) compared with the lower leaf surface and on the basal half of the leaves $(68.3 \%, G=$

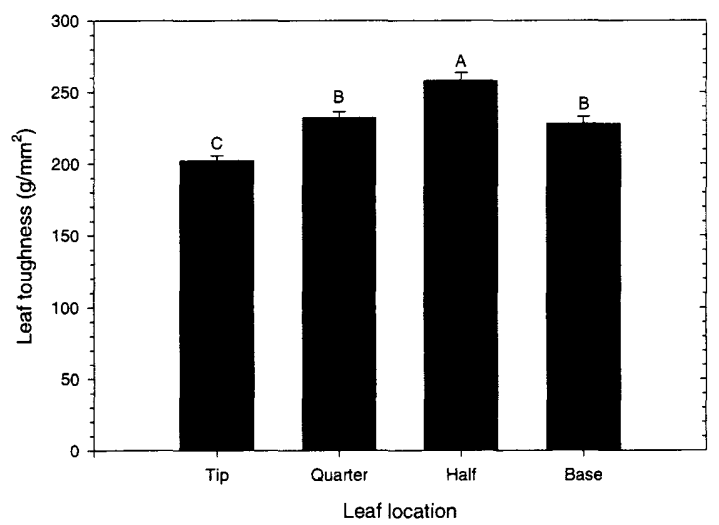

Fig. 1. Toughness (mean $\pm \mathrm{SE}$ ) of different locations on the $P$. stratiotes leaf. Bars with the same letter are not significantly different (Ryan $Q, P=0.05$ ). 
Table 2. Correlation coefficient matrix and significance levels among plant nutritional variables

\begin{tabular}{|c|c|c|c|c|c|c|c|c|c|c|}
\hline Variable & \multicolumn{2}{|c|}{ Nitrogen $^{a}$} & \multicolumn{2}{|c|}{$\mathrm{PO}_{4}^{a}$} & \multicolumn{2}{|c|}{$\mathbf{K}^{a}$} & \multicolumn{2}{|c|}{ Dry weight $^{a}$} & \multicolumn{2}{|c|}{ Toughness $^{b}$} \\
\hline Nitrogen & 1.0 & 0 & 0.6342 & 0.0913 & 0.2227 & 0.5961 & 0.1244 & 0.7692 & 0.2626 & 0.5693 \\
\hline $\mathrm{K}$ & & & & & 1.0 & 0 & -0.2170 & 0.6057 & -0.0364 & 0.9382 \\
\hline Dry weight & & & & & & & 1.0 & 0 & 0.9382 & 0.0062 \\
\hline Toughness & & & & & & & & & 1.0 & 0 \\
\hline
\end{tabular}

$$
\begin{aligned}
& { }^{a} n=8 . \\
& { }^{b} n=7 .
\end{aligned}
$$

$5.67, \mathrm{df}=1, P=0.025)$ compared with the apical half. However, the larvae were found equally on the inside and outside of the leaves $(G=1.23, \mathrm{df}=1, P>0.1)$.

Instar at Time of Death. The instar in which mortality occurred differed among the larvae fed leaves from the different treatments $(F=4.94$; $\mathrm{df}=7,121$; $P<0.0001$; Table 3 ). Nearly all the mortality occurred during the first 2 instars except for those fed leaves from the Torrey Island site; these larvae died most often as 3rd or 4th instars. The dead lst instars apparently never initiated feeding as they were commonly found either on the surface of the leaves or on the filter paper $1 \mathrm{~d}$ following the initiation of the experiment.

Instar at Pupation. The mean number of instars completed before pupation varied among larvae fed leaves from the different treatments $(F=8.22 ; \mathrm{df}=7$, 126; $P<0.0001$; Table 3 ). Pupation generally occurred after 7 instars in larvae fed the leaves from most of the treatments, whereas those fed the Loxahatchee- 1 and high leaves pupated after occasionally 5 , but typically 6 , instars. The gender of the individuals did not influence $(F=1.02 ; \mathrm{df}=1,131 ; P>0.3)$ the number of instars required prior to pupation (males: $6.6 \pm 0.5$ instars; females: $6.7 \pm 0.5$ ).

Larval Survival. Regression analysis indicated that leaf toughness contributed significantly only to larval survival (Fig. 2). Survival was greatest on the softest leaves $(72.5 \pm 9.5 \%)$ and was lowest on the tougher leaves $(13.3 \pm 4.8 \%)$. Leaf tip toughness was used instead of the toughness estimates from other leaf locations (i.e., quarter, half, or base) as it best pre-

Table 3. Instar at death or pupation (mean $\pm \mathrm{SE}$ ) for $S$. pectinicornis larvae fed $P$. stratiotes plants that were either field collected or cultured with low or high levels of fertilizer

\begin{tabular}{lcc}
\hline \hline \multirow{2}{*}{ Treatment $^{a}$} & \multicolumn{2}{c}{ Instar at } \\
\cline { 2 - 3 } & Death $\pm \mathrm{SE}$ & Pupation $\pm \mathrm{SE}$ \\
\hline LOX-1 & $1.8 \pm 0.3 \mathrm{~b}$ & $6.4 \pm 0.1 \mathrm{~b}$ \\
CM & $1.0 \pm 0.0 \mathrm{~b}$ & $7.0 \pm 0.0 \mathrm{a}$ \\
HIGH & $1.8 \pm 0.4 \mathrm{~b}$ & $6.3 \pm 0.1 \mathrm{~b}$ \\
LOX-2 & $1.4 \pm 0.2 \mathrm{~b}$ & $6.7 \pm 0.1 \mathrm{ab}$ \\
LOW & $1.6 \pm 0.4 \mathrm{~b}$ & $6.9 \pm 0.1 \mathrm{a}$ \\
PP & $1.9 \pm 0.6 \mathrm{~b}$ & $7.0 \pm 0.0 \mathrm{a}$ \\
CS & $1.4 \pm 0.3 \mathrm{~b}$ & $6.9 \pm 0.1 \mathrm{a}$ \\
TOR & $3.5 \pm 0.9 \mathrm{a}$ & $6.9 \pm 0.1 \mathrm{a}$ \\
\hline
\end{tabular}

Means within a column followed by the same letter are not significantly different (Ryan $Q, P=0.05$ ).

${ }^{a}$ LOX-1, Loxahatchee site 1; CM, Christmas Park; HIGH, high fertilizer; LOX-2, Loxahatchee site 2; LOW, low fertilizer; PP, Pioneer Park; CS, Cork Screw; TOR, Torrey Island. dicted larval survival. Neither phosphorus, potassium, dry weight, nor the interaction of nitrogen and toughness significantly $(\mathrm{P}>0.05)$ contributed to survival or the remaining performance parameters tested (i.e., developmental time, consumption, biomass gain) and therefore these independent variables were dropped from this and subsequent analyses.

Larval Developmental Time. Regression analysis indicated that larval developmental time did not vary significantly with regard to the nutritional parameters tested $(P>0.05)$. However, treatment differences in developmental time $(F=142.61 ; \mathrm{df}=7,485 ; P<$ 0.0001 ) were found among the sources of the leaves (Fig. 3). Development times were shortest for larvae fed the Loxahatchee-1 $(17.0 \pm 0.2 \mathrm{~d})$ and the high $(19.9 \pm 0.4 \mathrm{~d})$ fertilizer-treated leaves, whereas they were longest for those fed the Loxahatchee-2 (25.2 \pm $0.3 \mathrm{~d})$ and Torrey Island $(26.1 \pm 0.1 \mathrm{~d})$ leaves.

Larval Consumption. Regression analysis indicated that leaf nitrogen (percentage of fresh weight) contributed significantly only to larval consumption (Fig. 4). There was more than a 3 -fold increase in fresh weight consumption as the larvae fed the Loxahatchee-1 leaves consumed $2.19 \pm 0.11 \mathrm{~g}$ compared with $6.80 \pm 0.16 \mathrm{~g}$ on the Torrey Island leaves. Dry

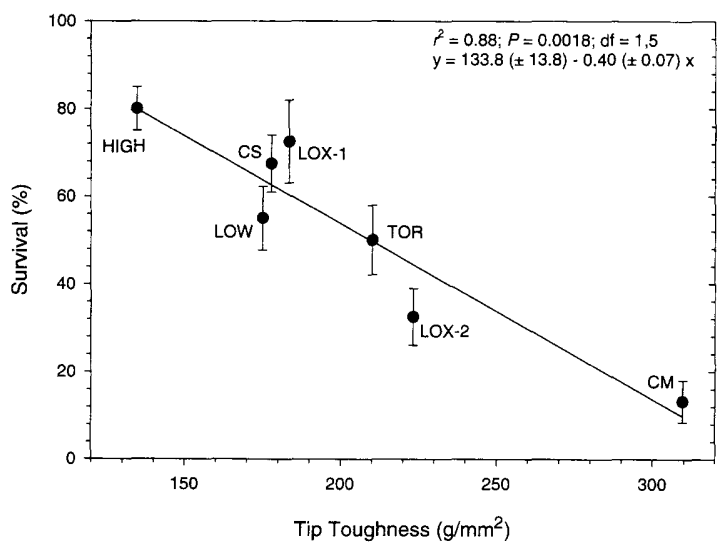

Fig. 2. Percentage of survival (mean $\pm \mathrm{SE}$ ) of S. pectinicornis larvae fed $P$. stratiotes leaves that were field collected or grown and fertilized having a range of leaf toughnesses. Regression $r^{2}$ value represents the partial $r^{2}$ from stepwise multiple regression analysis. LOX-1, Loxahatchee site 1 ; CM, Christmas Park; HIGH, high fertilizer; LOX-2, Loxahatchee site 2; LOW, low fertilizer; PP. Pioneer Park; CS, Cork Screw; TOR, Torrey Island. 


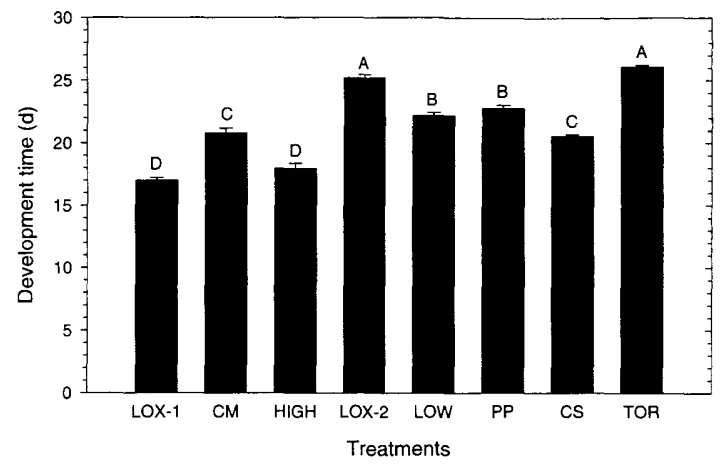

Fig. 3. Developmental time (days) (mean \pm SE) of S. pectinicornis larvae when fed $P$. stratiotes leaves that were field collected or grown and fertilized. Bars with the same letter are not significantly different (Ryan $O, P=0.05$ ). LOX-1, Loxahatchee site 1; CM, Christmas Park; HIGH, high fertilizer; LOX-2, Loxahatchee site 2; LOW, low fertilizer; PP, Pioneer Park; CS, Cork Screw; TOR, Torrey Island.

weight consumption also was influenced by dry weight nitrogen content of the leaves $\left(r^{2}=0.55, P=\right.$ 0.0568 ), though the variation explained by this variable was less than that of fresh weight consumption.

Larval Biomass Gain. Regression analysis indicated that larval biomass gain did not vary significantly with regard to the nutritional parameters monitored $(P>$ $0.05)$. However, treatment differences in biomass gain $(F=121.33 ; \mathrm{df}=7,485 ; P<0.0001)$ were found among the sources of leaves (Fig. 5). Biomass gain was greatest for larvae fed the high $(22.7 \pm 0.9 \mathrm{mg})$ fertilizer leaves, compared with those fed the Pioneer Park $(9.3 \pm 0.2 \mathrm{mg})$ and Christmas Park $(7.9 \pm 0.2 \mathrm{mg})$ leaves.

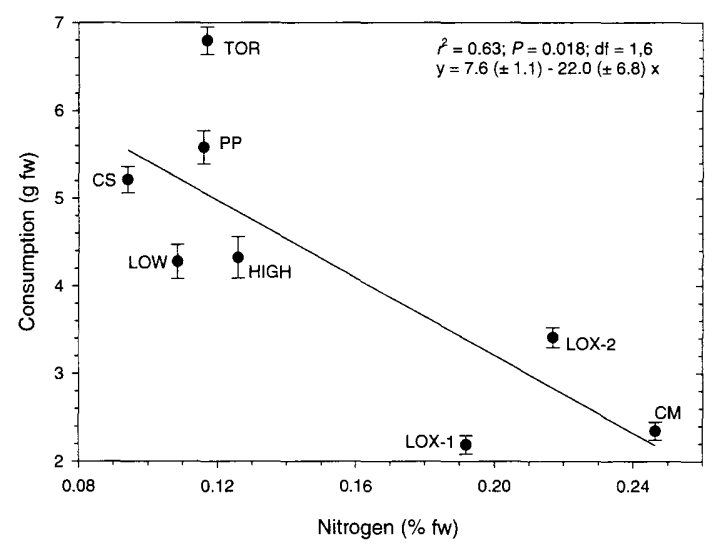

Fig. 4. Consumption (fresh weight, grams) (mean $\pm \mathrm{SE}$ ) of $S$. pectinicomis larvae as a function of leaf percentage of nitrogen (fresh weight) when fed P. stratiotes leaves that were field collected or grown and fertilized. Regression $r^{2}$ values represent the partial $r^{2}$ from stepwise multiple regression analysis. LOX-1, Loxahatchee site 1; CM, Christmas Park; HIGH, high fertilizer; LOX-2, Loxahatchee site 2; LOW, low fertilizer; PP, Pioneer Park; CS, Cork Screw; TOR, Torrey Island.

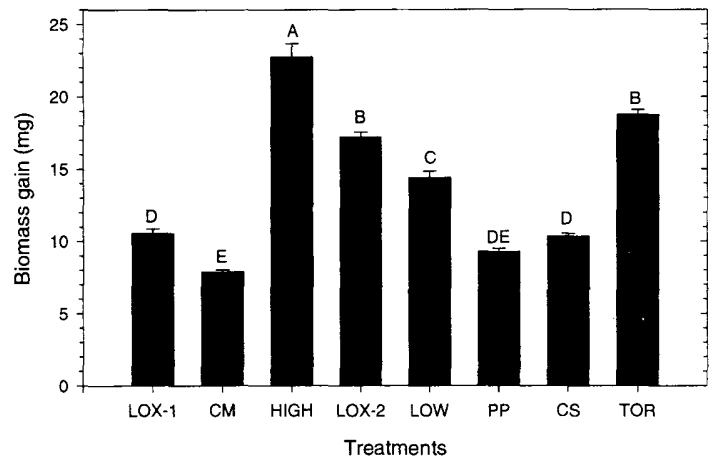

Fig. 5. Biomass gain (dry weight, $\mathrm{mg}$ ) (mean $\pm \mathrm{SE}$ ) of $\mathrm{S}$. pectinicomis larvae when fed $P$. stratiotes leaves that were field collected or grown and fertilized. Bars with the same letter are not significantly different (Ryan $Q, P=0.05$ ). LOX-1, Loxahatchee site 1; CM, Christmas Park; HIGH, high fertilizer; LOX-2, Loxahatchee site 2; LOW, low fertilizer; PP, Pioneer Park; CS, Cork Screw; TOR, Torrey Island.

\section{Discussion}

A wide range in leaf quality was found in the $P$. stratiotes plants collected from various sites or produced from our fertilizer treatments. Although S. pectinicornis larval survival was $80 \%$ on the softest leaves, it decreased to $13 \%$ when fed the tougher leaves. Much of the mortality occurred with the 1st instars that apparently were unable to penetrate the leaves and initiate feeding. Tissue toughness is known to be an important factor limiting herbivory (Coley 1983, Coley and Barone 1996) and it significantly affects the survival, growth, and development of other biological control agents (Wheeler and Center 1996, 1997). Leaf toughness is especially important to relatively small insects that feed and develop inside plant tissues ( $\mathrm{Ha}-$ gen and Chabot 1986, Kimmerer and Potter 1987). Although half the larvae observed in our study were found externally, their mandibles must penetrate the leaf to feed. Apparently this activity was restricted by the toughest leaves that contributed to the low larval survival. Considering the importance of leaf toughness for larval survival, we expected to find the larvae most often on the leaf tips as these were the softest tissues. However, the larvae were most often found on the basal half of the leaves, though further studies will have to be conducted that determine different larval activities (e.g., leaf penetration, feeding, resting) on different locations on the leaf.

Several factors contribute to foliage toughness, such as plant age (Feeny 1970, Hough and Pimentel 1978, Rausher 1981, Schultz et al. 1982, Coley 1983, Raupp 1985, Wright and Bourne 1986, Nichols-Orians and Schultz 1990), previous herbivory (Schultz and Baldwin 1982), increased $\mathrm{CO}_{2}$ environments (Lindroth et al. 1993), and growth in more sun-exposed sites (Lowman 1992, Dudt and Shure 1994, Lowman 1995). In our study, leaf toughness may have been influenced by differences in leaf exposure to sunlight, because leaves subjected to direct sunlight were tougher than those exposed to more shaded conditions. However, a sub- 
sequent study (G.S.W., unpublished data) indicated no difference in leaf toughness in $P$. stratiotes plants from shaded compared with exposed locations within the same site. Possibly the Christmas Park site, located at a more northern latitude $\left(28^{\circ} 30^{\prime}\right)$ than the other sites $\left(26^{\circ} 45^{\prime}\right)$, was influenced by cooler winter weather inducing senescence in the plants. Other observations (G.S.W., unpublished data) suggested that $P$. stratiotes leaves become tougher during cooler winter temperatures.

Leaf nitrogen content also affected larval performance because the larvae fed the low-nitrogen leaves increased their food consumption. The larvae responded to the low nitrogen levels by exhibiting compensatory feeding, resulting in a $>3$-fold increase in food intake. Although stepwise regression analysis indicated that developmental time and biomass gain were not related to nitrogen content or leaf toughness, differences in these performance values were found among treatments. This was unexpected as these nutritional factors frequently influence insect performance values (Mattson 1980, Coley and Barone 1996). However, larvae fed leaves from some sites that had high toughness (e.g., Torrey Island, Loxahatchee-2) had longer developmental times and those fed some low-nitrogen leaves (e.g., Pioneer Park, Corkscrew, Christmas Park) had low biomass gain. Undoubtedly several nutritional factors influence larval performance and possibly the interaction of these or additional factors not monitored here (e.g., defensive compounds) prevented the finding of significant relationships among the variables.

Extended larval development and increased larval feeding in particular (Bernays 1997) increases exposure to natural enemies (Loader and Damman 1991 , Benrey and Denno 1997). We expect exposure to parasitoids and predators to be greatest on the top surface of the leaves and, according to our results, this is the location occupied most often by these larvae. Field observations of larval locations on the leaves need be conducted to confirm these laboratory findings. Although several natural enemies have been reported attacking another lepidopterous herbivore, the pyralid Samea multiplicalis Guenée, which also feeds on P. stratiotes (Knopf and Habeck 1976), the susceptibility of S. pectinicornis to these natural enemy species has yet to be determined.

The relatively low levels of nitrogen (Slansky and Scriber 1985) found in the $P$. stratiotes plants reported here are further diluted by the high levels of water found in the foliage. If the nitrogen estimates (dry weight) are converted to their original fresh weight values-the condition more relevant to herbivore feeding behavior (Slansky 1993) - the nitrogen levels ranged from 0.09 to $0.25 \%$ fresh weight. These nitrogen levels (percentage fresh weight) for this floating aquatic species are similar to the submersed aquatic plant hydrilla (Wheeler and Center 1996). If this same level of nitrogen was found in a plant that contained $80 \%$ water, as is commonly found in terrestrial plants (instead of the 91 to $95 \%$ water reported here), these nitrogen values would have ranged from 0.30 to $0.57 \%$ fresh weight. Our results indicate that these levels are not much different from terrestrial plants on a dry weight basis (Lodge 1991, Newman 1991), but when the dilution effect due to water is considered, they are among the lowest nitrogen levels reported in plants and constitute a significant challenge to the growth and development of herbivores. Although dietary water can be in low quantities in many herbivore foods (e.g., trees; Mattson and Scriber 1987), we suggest that high levels of dietary water combined with relatively low levels of foliar nutrients can constitute a formidable barrier to herbivores. This effect may become even more important when combined with mortality from natural enemies.

Low nutrient levels have been proposed to function as antiherbivore defenses by decreasing the availability of essential nutrients (Feeny 1976, Rhoades and Cates 1976). To demonstrate that low nutrient levels function as an antiherbivore defense we need to show, at least partially, that these low nutrient levels are under genetic control and that they confer a benefit in terms of increased plant fitness in the presence of herbivory (Berenbaum 1995). However, we are unaware of any studies that have demonstrated a genetic link between increased plant fitness associated with low nutrients and herbivory. Moreover, this form of defense may be unlikely to evolve under most conditions (Berenbaum 1995). It may be effective in some circumstances such as against species that can perceive and avoid low-nutrient plants or against herbivore species that prolong development and are thus more susceptible to attack by natural enemies (Moran and Hamilton 1980). However, this mechanism is unlikely to evolve against species that can compensate for low-nutrient plants, such as S. pectinicornis (Berenbaum 1995). Possibly, low nutrient levels can act together with chemical defenses, resulting in compensatory feeding and increased ingestion of a toxic substance (Slansky and Wheeler 1992). Eight flavonoid compounds have been reported from P. stratiotes leaves (Zennie and McClure 1977), several of which have shown activity in insects (Hedin et al. 1983, Matsuda and Matsuo 1985, Feeny et al. 1988, Nishida et al. 1987). However, the effects these or other compounds have on $P$. stratiotes herbivores have yet to be determined.

Our release and establishment activities of this biological control agent benefited from these results. The initial release site (September 1995) for this species was located at Christmas Park where the relatively high nitrogen content of the leaves was expected to benefit the larvae, providing suitable nutrition and possibly stimulating an outbreak population. However, the selection of release sites was changed to include higher quality sites (e.g., Loxahatchee-1), considering the improved survival and larval performance demonstrated here. Further, we used this information to develop mass-rearing techniques where the larvae fed the softer, more nutritious plants had the greatest biotic potential because they required less time between generations and would be expected to produce more progeny (Wheeler et al. 1998). Addi- 
tionally, we modified the release sites by producing field nurseries consisting of fertilized plants that were protected from large $(>2.5 \mathrm{~cm})$ natural enemies. Preliminary results (unpublished data) suggest that these techniques assisted in the establishment of this species as indicated by an increased rate of recovery of released individuals and their progeny. However, a longer-term study is presently underway to determine the persistence of these established populations.

\section{Acknowledgments}

We thank R. Leidi-Ferrer, A. Bishop, L. Kasarjian, and A Durden (FLREC, University of Florida, Ft Lauderdale, FL) for technical assistance; Banpot Napompeth (National Biological Control Research Center, Bangkok, Thailand) for supplying S. pectinicornis; and B. Blossey (Cornell University, Ithaca, NY), D. R. Horton (USDA-ARS, Wapato, WA), and R. M. Newman (University of Minnesota, St. Paul, MN) for valuable comments on a previous draft of the manuscript Financial support was provided by the Southwest Florida Water Management District, Florida Department of Environmental Protection, and the U.S. Army Corps of Engineers

\section{References Cited}

Benrey, B., and R. F. Denno. 1997. The slow-growth-highmortality hypothesis: a test using the cabbage butterfly. Ecology 78: 987-999.

Berenbaum, M. R. 1995. Turnabout is fair play: secondary roles for primary compounds. J. Chem. Ecol. 21: 925-940

Bernays, E. A. 1997. Feeding by lepidopteran larvae is dangerous. Ecol. Entomol. 22: 121-123.

Center, T. D. 1994. Biological control of weeds: waterhyacinth and waterlettuce, pp. 481-521. In D. Rosen, F. D Bennett, and J. L. Capinera [eds.], Pest management in the subtropics: biological control-a Florida perspective. Intercept, Andover, UK.

Coley, P. D. 1983. Herbivory and defensive characteristics of tree species in a lowland tropical forest. Ecol. Monogr. 53: $209-233$

Coley, P. D., and J. A. Barone. 1996. Herbivory and plant defenses in tropical forests. Annu. Rev. Ecol. Syst. 27 305-335.

Cook, C.D.K., B. C. Gut, E. M. Rix, J. Schneller, and M. Seitz. 1974. Water plants of the world. Junk, The Hague.

Day, R. W., and G. P. Quinn. 1989. Comparisons of treatments after an analysis of variance in ecology. Ecol Monogr. 59: 433-463.

Draper, N., and H. Smith. 1981. Applied regression analysis, 2nd ed. Wiley, New York.

Dray, F. A., Jr., and T. D. Center. 1989. Seed production by Pistia stratiotes L. (waterlettuce) in the United States. Aquat. Bot. 33: 155-160.

1992. Biological control of Pistia stratiotes L. (waterlettuce) using Neohydronomus affinis Hustache (Coleoptera: Curculionidae), pp. 1-58. In Aquatic plant control research program. Technical Report A-92-1. U.S. Army Engineer Waterways Experiment Station, Vicksburg, MS.

Dray, F. A., Jr., T. D. Center, D. H. Habeck, C. R. Thompson, A. F. Cofrancesco, and J. K. Balciunas. 1990. Release and establishment in the southeastern United States of Neohydronomus affinis (Coleoptera: Curculionidae), an herbivore of waterlettuce. Environ. Entomol. 19: 799-802.
Dudt, J. F., and D. J. Shure. 1994. The influence of light and nutrients on foliar phenolics and insect herbivory. Ecology 75: 86-98.

Feeny, P. P. 1970. Seasonal changes in oak leaf tannins and nutrients as a cause of spring feeding by winter moth caterpillars. Ecology 51: 565-581.

1976. Plant apparency and chemical defense. Recent Adv. Phytochem. 10: 1-40.

Feeny, P. P., K. Sachdev, L. Rosenberry, and M. Carter. 1988. Luteolin-7-O-(6" -O-Malonyl)- $\beta$-D-Glucoside and TransChlorogenic acid: oviposition stimulants for the black swallowtail butterfly. Phytochemistry 11: 3439-3448.

Greenberg, A. E., L. S. Clesceri, and A. D. Eaton. 1992. Standard methods for the examination of water and wastewater, 18th ed. American Public Health Association, Washington, DC

Habeck, D. H., and C. R. Thompson. 1994. Host specificity and biology of Spodoptera pectinicornis (Lepidoptera, Noctuidae), a biological control agent of waterlettuce (Pistia stratiotes). Biol. Control 4: 263-268.

Hach, C. C., B. K. Bowden, A. B. Koplove, and S. V. Brayton. 1987. More powerful peroxide Kjeldahl digestion method. J. Assoc. Off. Anal. Chem. 70: 787.

Hagen, R. H., and J. F. Chabot. 1986. Leaf anatomy of maples (Acer) and host use by Lepidoptera larvae. Oikos 47: 335-345.

Hedin, P. A., J. N. Jenkins, D. H. Collum, W. H. White, W. L. Parrott, and M. W. MacGown. 1983. Cyanidin-3- $\beta$-glucoside, a newly recognized basis for resistance in cotton to the tobacco budworm Heliothis virescens (Fab.) (Lepidoptera: Noctuidae). Experientia 39: 799-801.

Holm, L. G., D. L. Plucknett, J. V. Pancho, and J. P. Herberger. 1977. The world's worst weeds: distribution and biology. University of Hawaii, Honolulu.

Hough, J. A., and D. Pimentel. 1978. Influence of host foliage on development, survival, and fecundity of the gypsy moth. Environ. Entomol. 7: 97-102.

Kimmerer, T. W., and D. A. Potter. 1987. Nutritional quality of specific leaf tissues and selective feeding by a specialist leafminer. Oecologia (Berl.) 71: 548-551.

Knopf, K. W., and D. H. Habeck. 1976. Life history and biology of Samea multiplicalis. Environ. Entomol. 5: 539542 .

Lindroth, R. L., K. K. Kinney, and C. L. Platz. 1993. Response of deciduous trees to elevated atmospheric $\mathrm{CO}_{2}$ : productivity, phytochemistry, and insect performance. Ecology 74: 763-777.

Loader, C., and H. Damman. 1991. Nitrogen content of food plants and vulnerability of Pieris rapae to natural enemies. Ecology 72: 1586-1590

Lodge, D. M. 1991. Herbivory on freshwater macrophytes. Aquat. Bot. 41: 195-224.

Lounibos, L. P., and R. L. Escher. 1985. Mosquitoes associated with water lettuce (Pistia stratiotes) in southeastern Florida. Fla. Entomol. 68: 169-178.

Lowman, M. D. 1992. Leaf growth dynamics and herbivory in five species of Australian rain forest canopy trees. J. Ecol. 80: 433-447.

1995. Herbivory as a process in rain forest trees, pp. 431455. In M. D. Lowman and N. M. Nadkarni [eds.], Forest canopies. Academic, New York.

Maddox, D. M., and M. Rhyne. 1975. Effects of induced host-plant mineral deficiencies on attraction, feeding, and fecundity of the alligatorweed flea beetle. Environ. Entomol. 4: 682-686

Matsuda, K., and H. Matsuo. 1985. A flavonoid, luteolin-7glucoside, as well as salicin and populin, stimulating the 
feeding of leaf beetles attacking salicaceous plants. Appl. Entomol. Zool. 20: 305-313.

Mattson, W. J. 1980. Herbivory in relation to plant nitrogen content. Annu. Rev. Ecol. Syst. 11: 119-161.

Mattson, W. J., and J. M. Scriber. 1987. Nutritional ecology of insect folivores of woody plants: nitrogen, water, fiber, and mineral considerations, pp. 105-146. In F. J. Slansky and J. G. Rodriquez [eds.], Nutritional ecology of insects, mites, spiders, and related invertebrates. Wiley, New York.

Moran, N., and W. D. Hamilton. 1980. Low nutritive quality as defense against herbivores. J. Theor. Biol. 86: 247-254.

Napompeth, B. 1982. Biological control research and development in Thailand, pp. 301-323. In D. L. Heong, B. S. Lee, T. M. Lim, C. H. Teoh, and Y. Ibrahim [eds.], Proceedings of the International Conference on Plant Protection in the Tropics. Malaysian Plant Protection Society, Kuala Lumpur, Malaysia.

Newman, R. M. 1991. Herbivory and detritivory on freshwater macrophytes by invertebrates: a review. J. N. Am Benthol. Soc. 10: 89-114.

Nichols-Orians, C. M., and J. C. Schultz. 1990. Interactions among leaf toughness, chemistry, and harvesting by attine ants. Ecol. Entomol. 15: 311-320.

Nishida, R., T. Ohsugi, S. Kokubo, and H. Fukami. 1987. Oviposition stimulants of a Citrus-feeding swallowtail butterfly, Papilio xuthus L. Experientia 43: 342-344.

Orr, B. K., and V. H. Resh. 1992. Influence of Myriophyllum aquaticum cover on Anopheles mosquito abundance, oviposition, and larval microhabitat. Oecologia (Berl.) 90: $474-482$.

Raupp, M. J. 1985. Effects of leaf toughness on mandibular wear of the leaf beetle, Plagiodera versicolor. Ecol. Entomol. 10: 73-79.

Rausher, M.D. 1981. Host plant selection by Battus philenor butterflies: the roles of predation, nutrition, and plant chemistry. Ecol. Monogr. 51: 1-20.

Rhoades, D. F., and R. G. Cates. 1976. Toward a general theory of plant antiherbivore chemistry. Recent Adv. Phytochem. 10: 168-213.

Room, P. M. 1990. Ecology of a simple plant-herbivore system: biological control of Salvinia. Trends Ecol. Evol. 5: 74-79.

SAS Institute. 1988. SAS/STAT user's guide, release 6.08. SAS Institute, Cary, NC.

Schultz, J. C., and I. T. Baldwin. 1982. Oak leaf quality declines in response to defoliation by gypsy moth larvae. Science (Wash. D.C.) 217: 149-151.
Schultz, J. C., P. J. Nothnagle, and I. T. Baldwin. 1982. Seasonal and individual variation in leaf quality of two northern hardwoods tree species. Am. J. Bot. 69: 753-759.

Slansky, F., Jr. 1993. Nutritional ecology: the fundamental quest for nutrients, pp. 29-91. In N. E. Stamp and T. M. Casey [eds.], Caterpillars: ecological and evolutionary constraints on foraging. Chapman \& Hall, New York

Slansky, F., Jr., and J. M. Scriber. 1985. Food consumption and utilization, pp. 87-163. In G. A. Kerkut and L. I. Gilbert [eds.], Comprehensive insect physiology, biochemistry and pharmacology. Pergamon, Oxford.

Slansky, F. Jr., and G. S. Wheeler. 1992. Caterpillars' compensatory feeding response to diluted nutrients leads to toxic allelochemical dose. Entomol. Exp. Appl. 65: 171186.

Sokal, R. R., and F. J. Rohlf. 1981. Biometry: the principles and practice of statistics in biological research, 2nd ed. Freeman, New York.

Taylor, M.F.J. 1984. The dependence of development and fecundity of Samea multiplicalis on early larval nitrogen intake. J. Insect Physiol. 30: 779-785.

1988. Field measurement of the dependence of life history on plant nitrogen and temperature for a herbivorous moth. J. Anim. Ecol. 57: 873-891.

Tucker, C. S. 1981. Relationships between culture density and the composition of three floating aquatic macrophytes. Hydrobiologia 85: 73-76.

Wheeler, G. S., and T. D. Center. 1996. The influence of hydrilla leaf quality on larval growth and development of the biological control agent Hydrellia pakistanae (Diptera: Ephydridae). Biol. Control 7: 1-9.

1997. Hydrilla stem quality influences the growth and development of the biological control agent Bagous hydrillae. Biol. Control 8: 52-57.

Wheeler, G. S., T. K. Van, and T. D. Center. 1998. The influence of Pistia stratiotes plant quality on fecundity and egg distribution of the biological control agent Spodoptera pectinicornis. Entomol. Exp. Appl. 86: 295-304.

Wright, A. D., and A. S. Bourne. 1986. Effect of leaf hardness on penetration of waterhyacinth by Sameodes albiguttalis. J. Aquat. Plant Manage. 24: 91-92.

Zennie, T. M., and J. W. McClure. 1977. The flavonoid chemistry of Pistia stratiotes L. and the origin of the Lemnaceae. Aquat. Bot. 3: 49-54.

Received for publication 11 July 1997; accepted 18 February 1998. 